\title{
Re-Valuing Women's Knowledge
}

\author{
Hilary Yerbury \\ University of Technology, Sydney
}

\begin{abstract}
Women's knowledge has often been seen as 'a whole set of knowledges that have been disqualified as inadequate to their task or insufficiently elaborated: naive knowledges, located low down on the hierarchy, beneath the required level of cognition or scientificity' (Foucault 1980, p. 82). The purpose of this paper is to explore the assertion that women's knowledges are inadequate and to document ways in which they are marginalised so that the hierarchical nature of scientific practice can be understood and the contributions of women and all those from the Global South can be recognised and facilitated. Revaluing women's knowledge is recognised as one of the most direct methods of changing the way a society works. A vast literature (eg Sen 1999) has argued that women's knowledges are a key factor in development and have been shown to lead to poverty alleviation, to the development of active citizens and to the creation of a more open and democratic society. Possibilities for the revaluing of women's knowledges and the democratization of access to scientific knowledge using information and communication technologies are considered, focussing on the concepts of open access and the information commons.
\end{abstract}

\section{Introduction}

Foucault argued that, traditionally, scientific discourse and the way it was presented was the basis of truth in a society and that truth was incorporated in the processes that generated the statements in this discourse and oversaw their distribution and circulation in society. Traditional knowledge, then, by its nature, cannot be deemed truth. It is not a scientific discourse, there are no institutions as such which oversee its production, regulation and distribution and there is rarely a system of procedures or a system of power which oversees it. Many women’s knowledges are deemed not scientific but rather belong to a category of naïve knowledges. These knowledges are not created or validated through institutions in society. They are often referred to as traditional knowledge or indigenous knowledge and thus separated from scientific knowledge. Thus, they are not the concern of this paper, even though indigenous knowledge is socially and contextually situated and if it is ignored in programs for development, these programs are very likely to be less successful (Brokensha et al. 1980 in Agrawal 1995; Munk 2013).

Women interested in scholarship and research have not always been treated in the same way as their male peers, even when their knowledges have not been considered inferior. Marie Curie, for example, was refused membership in the French Academie des Sciences in 1911, 
in spite of having won two Nobel prizes. Although we are no longer at this point in history, throughout the world, women scholars have not found their rightful place, especially in the sciences and technology. There are two key reasons relevant to this paper. Firstly, those who have established themselves as women scientists are only a tiny minority of those who began their education at the primary school level. Women are under-represented in many areas of employment and in science and technology in particular. Secondly, those who have managed to establish themselves as scientists do not find the same recognition as their male counterparts especially in the developing world (Gülser Corat 2010). Both men and women from the Global South struggle for recognition as scholars in a system that favours an AngloAmerican approach to scholarship (Murphy \& Zhu 2012).

\section{Knowledges 'disqualified as inadequate'}

Women are under-represented in science and technology in universities and research institutes. In 2005, Lawrence Summers, the President of Harvard, presented the essentialist argument that there were two reasons for this under-representation, the first being that they were not prepared to work the long hours necessary to be successful and the second that girls are inherently less able than boys in science related subjects. Symonds et al. (2006) in an Australia study aiming in part to test Summers's assertion, found that indeed men were on average $40 \%$ more productive than women and that this discrepancy appeared early in their careers, "in the second year after their first publication”. However, after the initial two or three years, women have the same publication rate as men. The consequence of this is that men appear to be more productive than women of equal experience and therefore they gain the promotions and the research funding (Glimcher \& Lieberman 2009). A pattern of claim and counter claim pervades the literature on scientific productivity (Prpic et al. 2009) and is not limited to studies of scientists from the Global South (Davarpanah \& Moghadam 2012).

Little of this essentialist literature considers the factors which may have resulted in women being under-represented in science, writing fewer articles or submitting fewer patents. These factors may stem from childhood experiences, where girls may perceive science as gendered and intellectual inclined girls and women are seen as social losers. The difficulties girls have with maths are not given the same attention as boys' problems with reading. The culture in classrooms and scientific laboratories is often hostile to girls and women, with the 
expectations of bench practices often conflicting with the demands of domestic life, especially if the women have children.

Women in the West are gaining degrees, including doctoral degrees, in ever increasing numbers, albeit not necessarily in the physical sciences, maths and engineering. However, in the Global South, the exclusion of girls from education, especially beyond primary school, markedly affects their participation in the sciences and technologies. Many governments in the South appreciate the importance of an educated citizenry and in particular of the need to draw on the knowledge and skills of women to eradicate poverty, but have great difficulties in providing the opportunities for girls to complete their education. Rwanda is an example of a country which struggles to keep girls in secondary education, with a number of excellent programs, and is not yet able to provide opportunities for university education on a par with those in the West, as the provision of tertiary education, particularly in the sciences is so costly. In Rwanda, there is gender parity in primary education but the achievements of boys outstrip the achievements of girls even at primary level and that gap widens in secondary school, being very wide in science, mathematics and technology subjects. In part, this may be because science and technology subjects are potentially more costly than subjects in the humanities and girls may be more likely to miss out on the more expensive subjects than boys. It may also be because the topics studied are not immediately relevant to girls (Masanja 2010). Other reasons include the lack of female teachers both in schools and in the University (only 21\% of academics at the National University of Rwanda in 2012 were female (Masanja, pers. comm. 2012) and the very small numbers of female role models in schools and in the community. Throughout the Global South, at the university level, small numbers of eligible women are likely to enrol in courses ${ }^{1}$.

\section{Excluded from the research process}

In the world of scholarship, it has been assumed that the best way to create scholarly knowledge is to carry out research and publish the outcomes. Women's knowledges and experiences have been excluded from the processes of formulating research questions until recently, in part because they have been excluded as researchers, as noted above, and their

\footnotetext{
${ }^{1}$ Even in the Australia, where numbers of female students are likely to be at least equal to the number of males, the number of female students in Science and Technology is often low; at the University of Technology, Sydney, in 2010 for the first time, female students were in the majority (51\%) (UTS 2010), but only 14\% of the undergraduate students enrolled in the Faculty of Engineering and Information Technology were female.
} 
voices have been missing from the data collected in many studies because women and girls were not included as participants. In this way, women's knowledges were systematically excluded from policy-making and from investment and other decisions made on the basis of research results. Thus, any approach to increasing the numbers of women in science has to be supplemented by programs which change the way that research questions are posed, for example by incorporating gender analysis into basic and applied research (Schiebinger \& Schraudner 2011). Without this kind of systematic analysis, we are left with isolated examples of women's perspectives being incorporated into scientific research. Research into breast cancer and its treatments is one field where the inclusion of women's voices and a female perspective on a personal and societal problem significantly changed the understanding of these problems. As a consequence, radical mastectomy is no longer considered the only avenue of treatment. This pressure to ask research questions relevant to women can also be seen behind the US reforms of the 1990s which required that women be included in clinical trials of drugs. Until that point, almost all treatments of heart disease for example had been studied on groups of men, even when the concern had been with the effects of the female hormone oestrogen.

Women are often excluded as practitioners of research, even when they are employed as academics. They are likely to be employed at junior levels and on temporary contracts. Thus they are not part of strong research communities and therefore have lower social capital. This is important because those with higher social capital are more likely to be involved in the discussion of research questions and in the setting of research agendas. They are also more likely to have the relationships and ties that will help them with problem solving. People with higher social capital are likely to experience higher levels of trust and to be valued more highly within a group. In the context of research, one way to identify levels of social capital is to explore the collaborations researchers are engaged in. In general, women scientists are more likely to collaborate with other women than are male scientists. According to Bozeman and Corley (2004) those women who do not hold a tenure track position have $84 \%$ of their collaborations with other women. The reason for this is not clear, although it may be further evidence that the women at the bottom of the university hierarchy are not invited by men to take part in research teams. Interestingly, however, in this study, men were more likely to mentor women. The reason for this is not clear, but it may be that some male scientists recognise that women have had fewer opportunities to develop their knowledge and skills and 
that this is a pre-requisite to developing the trust that can lead to social capital (Bozeman \& Corley 2004, p. 611).

Women's contribution to scientific knowledge can be minimised in other ways. In Australia, for example, indigenous women are acknowledged as knowledge specialists and what they know is recognised as being of great benefit to their own community and with the potential to support development in other communities. This acknowledgement and recognition however may become problematic. According to the Australian NGO Shadow Report on the Implementation of the Convention on the Elimination of All forms of Discrimination Against Women (CEDAW) (Koorie Women Mean Business 2005), indigenous women complain that they do not get paid as knowledge specialists. Rather, consultants work with women to understand their specialist knowledge, which is then transferred out of the community, with no recompense to the community. The consultants often gain a double benefit from their involvement - they are well-paid and their work with the knowledge of indigenous women may bring them academic qualifications and scholarly renown through scientific research reports.

\section{Publications "Low down in the hierarchy"}

Scientists and scholars from countries which are not English-speaking and which have not been part of the western scholarly tradition find that the journals and other publication outlets available to them are rarely considered important by scholars from the US, UK or Australia. Lists of journals which are 'recognised' as meeting standards of quality set by governments, such as the list generated for Australia's Excellence in Research for Australia contains very few journals published in languages other than English. Lists such as these encourage patterns of publishing since scholars' recognition and acceptance are key to the process of developing new knowledges.

For the African woman and scholar, for example, there are many obstacles to the recognition and acceptance of her knowledges and scholarship. Her knowledges are often 'disqualified' in the ways that women's knowledges in other places are deemed less valid or less important. As an African, her knowledges and scholarship are 'located low down in the hierarchy' for a range of additional reasons, related to 'the institutions which produce [knowledge]'. African knowledge about Africa is swamped by Western knowledge about Africa. The World Bank 
report on Extending African Knowledge Infrastructure (Jackson et al. 2008) reported that the majority of books and journals on Africa are held in libraries and other repositories in the West and that databases and websites of resources about Africa are also predominantly held in the West. A report by Thomson Reuters (2010), producers of the significant Web of Science database, analysed research publications in Africa. It noted that although great gains have been made in the publishing of scholarly literature in the previous ten years, nonetheless, the whole continent of Africa produces about the same number of scholarly articles each year as the Netherlands, a small European country in terms of scientific output. The most productive countries are: South Africa, Egypt and Kenya. Rwanda is one of several countries producing fewer than 20 scholarly articles published in journals covered by Web of Science in 2008. Rwanda also appears to have a relatively low level of collaboration with scholars in other countries, fewer than the five papers per year required for inclusion in the analysis of international collaborations. This picture was no less bleak in the UNESCO Science Report of 2010, where it is also reported that no patents have been granted to Rwandan inventors by the US Patents Office in the period 2005 - 2009.

These reports of non-existent dissemination of knowledge do not necessarily reflect the endeavours of African scholars. Many African scholars publish their findings in reports and technical papers or in working papers or conference proceedings which do not become part of the formal publishing record and therefore are not accessible to other scholars (Abrahams et al 2008).This approach is not limited to women from Africa. Women working for social change in Australia are also more likely to discuss their work at conferences or professional meetings or to produce working papers for dissemination among other practitioners and policy makers, according to the anecdotal evidence of women experts.

\section{Overwhelmed by power of Western publishers}

To continue the consideration of disadvantage of African scholars, even if African scholars do try to publish the results of their research in established (Western) scholarly journals, they may be overwhelmed by the hegemony of the major journals and their publishers. The editor of the Lancet, a major British medical journal, is reported to have said that 'if he chose to publish African authors, this might reduce the citation impact of his journal', leading to a situation that he describes as 'a racist culture in journal decision-making' (Gray 2010, p. 10). A similar point is made by van der Werf-Davelaar (2006) who notes that Dutch scholars 
researching African questions felt that the emphasis on citation and impact measures was forcing them to publish in journals not read by their African peers.

The objectives of scholarly production in the Global South may be different from those in the hegemonic West, again leading to under-representation of these knowledges in the scientific record of so-called 'world-class' journals. Scholarship in the Global South may be more concerned with practical relevance than with empirical study, an approach which is deemed "unpublishable” in these Western journals. In an attempt to get published, scholars are using exotic Western research concepts to appeal to the editors of these journals and ignoring their own contexts. The consequences of this include derivative work whose authors produce sound technical data analysis and who have ignored their own scholarly context (Xi \& Han 2010; Keim 2011).

The power of the large publishing houses in controlling the flow of knowledge cannot be underestimated. Elsevier now publishes about $20 \%$ of the key scholarly journals. The days when journals were published by scholarly or professional associations or by universities or research centres have passed and with them, the days when a subscription to a journal meant ownership of a physical copy of a journal and the potential for preferential rates for those less able to pay. Instead, companies like Thomson Scientific control access to scholarly knowledge and are thus able to decide which journals to include in their electronic databases and how much to charge. In Australia, between 1986 and 1998, the number of journal subscriptions in university libraries declined by $37 \%$ and expenditure on them increased by $63 \%$. The unit cost of a journal subscription increased by 474\% (Houghton 2001).

Without access to new scholarly knowledge, students and researchers alike are denied the opportunity to explore new ideas and different ways of knowing. In developing countries, these moves by the major publishing houses have marginalised scholars even further by minimising their access to scholarly knowledge taken for granted in many institutions in the West. There are a number of programs, for example supported by UNESCO, which have made available full text data bases to libraries in developing countries, and these will go some way towards giving opportunities for exploring new ideas and different ways of knowing. 


\section{The need for a moral framework}

Lor and Britz, from the University of Pretoria, argue that the current information flows between North and South and South-South raise moral questions and that a moral framework should underpin any attempts to redress inequities in information flows. They argue that 'justice is the main normative tool that can be used to regulate world information flows' and identify four types of justice. Distributive justice implies that information is available fairly and equally to support everyday living and to enhance understanding and exchange of ideas. Contributive justice, which brings together the individual and the common good, implies that African scholars have a responsibility to make their research findings and knowledges available to others throughout the world and that systems of scholarly communications have a responsibility to acknowledge and accept the work of African scholars. Commutative justice is about a fundamental fairness in interactions, so that knowledges generated in the South should not be taken and used elsewhere without acknowledgement and recompense.

Retributive justice is about the possibility of taking action against those who infringe moral rights and the principles of justice. In information flow terms, this assumes the protection of the interests of the owners and producers of knowledge, not only in terms of intellectual property but also in terms of traditional knowledges (2006).

Working from these principles, Lor and Britz (2006) identify the open access movement as an encouraging development in increasing information flows. Open access includes peerreviewed open access journals, e-print repositories and institutional repositories. The open access movement includes many initiatives by scholars, research libraries, foundations, public interest institutions and many collaborations among and between them. There are already many examples of open access journals bringing about the re-valuing of African scholarly knowledge. The African Journals Online project is testament to the success of this venture. Using the Open Journal System software, the scheme hosts over 380 peer-reviewed journals from 29 countries. This project helps to address the problem referred to earlier, that African scholars find it difficult to gain recognition and publication of their work in Western scholarly journals. It is now run through a non-profit organization, based in South Africa.

\section{The Knowledge Commons and Civil Society}

Elinor Ostrom and Charlotte Hess propose the notion of the information or knowledge commons (Hess and Ostrom 2006) as a way of making scientific knowledge more widely available. Ostrom was awarded the Noble Prize for economics in 2006, the first woman to 
win the prize in this field, for her pioneering work in showing that common resources can be successfully managed by the people who use them, rather than by governments or private companies. A commons is a resource shared by a group of people.

Ostrom and Hess argue that the knowledge commons has its origins in notions of democracy and freedom, based in openness and inclusiveness. They propose (2006, p. 6) that collective action, self-governance and social capital are key factors in the development and success of commons and note that although the open access movement might be seen to be similar to the knowledge commons, there are differences. They emphasise the importance of the social interactions involved in creating a knowledge commons and assert that as with any other social interaction, the outcomes can be beneficial or detrimental. Open access, on the other hand, sets out to provide a public good - free and unfettered access to information, while at the same time allowing authors to retain copyright.

Levine argues that there are two types of knowledge commons, the libertarian commons and the associational commons (Levine 2006). He argues that “open access” is an example of a libertarian commons. The key characteristics of a libertarian commons are that everyone has a right to use a public resource and that right usually derives from the law or at least a policy. The associational commons, which is at the heart of the knowledge commons proposed by Ostrom and Hess, is controlled by a group, such as a non-profit association or a community group, who 'band together to protect a public good'. For Levine, associational commons are central to civil society and he favours the associational commons over the libertarian commons because in an associational commons, there is a structure and individuals who have made a commitment to the commons and will be prepared to defend it. In a libertarian commons, there is always the problem that some people will exploit it and that law-makers and policy-makers will threaten the shared nature of the resource through political constraints of overprotection, such as censorship or claims of ownership. Further, he argues that the only value underpinning the libertarian commons is liberty whereas an association may support a number of values, including freedom, truth, sustainability, reliability, decency and public access.

Libraries have traditionally operated as knowledge commons and in Western countries they are seen as essential to the development of democratic societies. As knowledge commons they can provide an institutional approach to the revaluing of women's knowledge, through a 
variety of programs, including collection development programs which emphasise the work of women scholars and through providing training in information literacy which is considered fundamental to the development of knowledge and of democracy in the future (UNESCO 2007). In the context of the knowledge commons of libraries, it is important to ensure that young women who complete their education are well placed to reach their potential and develop and express their own knowledge and understandings with confidence.

There is also scope for women scholars to work together create associational knowledge commons and to establish a journal within this framework, which will support the scholarly work of women. The process of establishing and managing a scholarly journal provides opportunities to develop many skills which will be of use in the revaluing of women's knowledge. An editorial committee makes decisions on the scholarly direction of the journal and establishes the criteria for operation which underpin the integrity of the journal and the articles it publishes. It also takes responsibility for identifying reviewers to take part in the peer review process. More experienced women scholars can mentor younger scholars in the peer review process. It can also identify potential authors and seek ways to collaborate with scholars in universities and research centres to mentor less experienced writers, through workshops, writing groups and other mechanisms. Open access journals run through associational commons can provide a way to disseminate knowledge that may not be seen as a priority for the major commercial publishers, a category often largely comprising the work of women scholars.

\section{Conclusion}

This overview shows that women's knowledges are systemically undervalued and often disqualified because they seem 'beneath the required level of cognition and scientificity'. Yet, there are many voices urging women to claim positions as contributors to scholarly knowledge and policy development.A brief consideration of open access journal publishing and of knowledge commons suggests ways in which the knowledges of women scholars may be re-valued.

Re-valuing of women's knowledges will require effort from women scholars themselves.All women scholars and scholars in the Global South could heed the words of Mshaï Mwangola (2008), who offers sound advice on how to encourage the valuing of their scholarly 
knowledge. Addressing African women scholars, she urges them to find appropriate ways to communicate their scholarly knowledge to local audiences, not only writing scholarly articles but also becoming public intellectuals and using performance and journalism to communicate, especially when more traditional avenues for scholarly publication are closed. She encourages them to question the interpretive frameworks and research methodologies (2008 p.14) which underpin education and research so that African [women] can develop their own intellectual paradigms which reflect their position as 'African intellectuals participating in the global knowledge community’. She challenges young African scholars to take responsibility for their own development as scholars and to use all the techniques and strategies available to them, including the use of information technologies and other new ways of working.

\section{References}

Abrahams, L. et al. 2008, Opening Access to Knowledge in Southern African Universities, Southern African Universities Regional Association.

Agrawal, A. 1995, 'Indigenous and scientific knowledge: some critical comments', IK Monitor, vol.3, no. 3, http://www.nuffic.nl/ciran/ikdm/3-3/articles/agrawal.html Accessed 10 July 2013.

Bozeman, B. \& Corley, E. 2004, 'Scientists' collaboration strategies: implications for scientific and technical human capital’, Research Policy, vol.33, pp. 599-616. http://dx.doi.org/10.1016/j.respol.2004.01.008

Davarpanah, M. \& Moghadam, H. 2012, 'The contribution of women in Iranian scholarly publication', Library Review, vol. 61, no. 4, pp. 261-271. http://dx.doi.org/10.1108/00242531211267563

Foucault, Michel 1980, 'Two Lectures', in Gordon, C. (ed.), Power/Knowledge: Selected Interviews and Other Writings 1972 - 1977, Pantheon Books, New York.

Glimcher, L. \& Lieberman, J. 2009, 'Harvard's women four years later', Nature Immunology, vol.10, no.6, pp. 559 - 561. http://dx.doi.org/10.1038/ni0609-559

Gray, E. 2009/2010, ‘Access to Africa’s knowledge: publishing development research and measuring value', The African Journal of Information Communication, no.10, http://link.wits.ac.za/journal/AJIC10-print-full.pdf Accessed 10 December 2010.

Gülser Corat, S. 2010, 'Gendering the science and technology agenda', Gender, Science and Technology Expert Group Meeting, Paris, UNESCO.

http://www.un.org/womenwatch/daw/egm/gst_2010/presentations/PresentationUNESCO-BP2EGMST.pdf Accessed 10 July 2013.

Hess, C. \& Ostrom, E. 2006, 'Introduction' in Hess, C. \& Ostrom, E. (eds.), Understanding Knowledge as a Commons; from Theory to Practice, MIT Press, Cambridge, pp. 3-26. 
Houghton, J. 2001, 'Economics of Scholarly Communication, A discussion paper prepared for the National Scholarly Communications Forum', National Library of Australia, Canberra, 8th August 2001.

Jackson, S. et al. 2008, Extending African Knowledge Infrastructures: sharing, creating, maintaining; a report for the World Bank Knowledge for Development Program, http://hdl.handle.net/2027.42/61201 Accessed 10 July 2013.

Keim, W. 2011, 'Counterhegemonic currents and internationalization of Sociology', International Sociology, vol.26, pp. 123-145.

Koorie Women Mean Business 2005, Australian NGO Shadow Report on the Implementation of the Convention on the Elimination of All forms of Discrimination Against Women (CEDAW) 10 October 2005.

http://www.health.nt.gov.au/library/scripts/objectifyMedia.aspx?file=pdf/46/35.pdf\&sit eID=1\&str_title=CEDAW\%20Indigenous\%20Women\%20Shadow\%20Report\%20200 5.pdf Accessed 10 July 2013.

Levine, P. 2006, 'Collective action, civic engagement and the knowledge commons', in Hess, C. \& Ostrom, E. (eds.) Understanding Knowledge as a Commons; from Theory to Practice, MIT Press, Cambridge, pp.247 - 275.

Lor, P. and Britz, J. 2005, 'Knowledge production from an African perspective: international information flows and intellectual property', The International Information \& Library Review, vol.37, pp. 61-76. doi:10.1016/j.iilr.2005.04.003 Accessed 20 July 2013.

Masanja, V.G. 2010, 'Increasing women’s participation in science, mathematics and technology education and employment in Africa', United Nations Division for the Advancement of Women, Expert Group Meeting, www.un.org/womenwatch/daw/egm/gst_2010/Masanja-EP.8-EGM-ST.pdf, Accessed 10 December 2010.

Munk, N. 2013, The Idealist: Jeffrey Sachs and the Quest to End Poverty, Doubleday, New York.

Murphy, J. \& Zhu, J. 2012, 'Neo-colonialism in the academy? Anglo-American domination in management journals', Organization, vol. 19, pp. 915-927. doi:

10.1177/1350508412453097 Accessed 1 November 2013.

Mwangola, M. 2008, 'Nurturing the fourth generation: defining the historical mission for our generation', Africa Development, vol.33, no.1, pp. 7-24.

http://dx.doi.org/10.4314/ad.v33i1.57243

Prpic, K. 2009, Women in Science and Technology, Zagreb, Institute for Social Research Zagreb Sociology of Science and Technology Network of European Sociological Association.

Schiebinger, L. \& Schrauder, M. 2011, 'Interdisciplinary approaches to achieving gendered innovations in science, medicine and engineering’, Interdisciplinary Science Reviews, vol.36, no.2, pp. 154-167. doi:10.1179/030801811X13013181961518 Accessed 1 November 2013.

Sen, A. 1999, Development as Freedom, Oxford University Press, Oxford.

Summers, L. 2005, Remarks at NBER Conference on Diversifying the Science \& Engineering Workforce, 
http://web.archive.org/web/20080130023006/http://www.president.harvard.edu/speeche s/2005/nber.html Accessed 10 July 2013.

Symonds, M. et al. 2006, 'Gender differences in publication output: towards an unbiased metric of research performance’, PLoS One, vol.1, no.1.

http://www.plosone.org/article/info:doi/10.1371/journal.pone.0000127 Accessed on 10 July 2013.

Thomson Reuters 2010, Global Research Report; Africa.

http://researchanalytics.thomsonreuters.com/m/pdfs/globalresearchreport-africa.pdf Accessed 8 December 2010.

Thomson Reuters 2013, Global Research Report Africa, http://sciencewatch.com/sites/sw/files/sw-article/media/globalresearchreport-africa.pdf Accessed 20 July 2013.

UNESCO Information for All Programme 2007, Understanding Information Literacy: A Primer, UNESCO, Paris. http://unesdoc.unesco.org/images/0015/001570/157020e.pdf Accessed 31 December 2010.

UNESCO Science Report 2010, http://unesdoc.unesco.org/images/0018/001899/189958E.pdf Accessed 20 July 2013.

University of Technology, Sydney website 2010 http://www.uts.edu.au Accessed 10 December 2010.

Van der Werf-Davelaar, T. 2006, 'Facilitating scholarly communication in African Studies', D-Lib Magazine, vol.12, no. 2, http://dlib.anu.edu.au/dlib/february06/vanderwerf/02vanderwerf.html Accessed 10 July 2013. http://dx.doi.org/10.1045/february2006-vanderwerf

Xi, Y. \& Han, W. 2010, 'Dilemma of indigenous research in China', Journal of Xi'an Jiaotong University, vol.13. 